\title{
Preconditioning abolishion by midazolam in isolated hearts of rats ${ }^{1}$
}

\author{
Abolição do precondicionamento pelo midazolam em corações isolados de ratos
}

\author{
Otoni Moreira Gomes', Ubirajara Fernandes Valladares ${ }^{I I}$, Carlos Henrique Marques dos Santos ${ }^{\text {III, Rafael Diniz Abrantes }}{ }^{\text {IV }}$ \\ ${ }^{I}$ PhD, Full Professor, Surgery Department, Minas Gerais Federal University (UFMG) and São Francisco de Assis Cardiovascular Foundation, Belo \\ Horizonte - MG, Brazil. \\ ${ }^{\text {II }}$ Master, São Franscisco de Assis Cardiovascular Foundation, Belo Horizonte - MG, Brazil. \\ III PhD, Assistant Professor, Surgery Department, Mato Grosso do Sul Federal University (UFMS), Campo Grande - MS, Brazil. \\ Iv MD, Resident, Madre Tereza Hospital, Belo Horizonte - MG, Brazil.
}

\begin{abstract}
Purpose: To study the effects of benzodiazepine midazolam in the coronary flow (Cflo), cardiac frequency (CF) and myocardial contractility in isolated hearts of rats subjected to ischemic preconditioning (IPC). Methods: 30 Wistar rats were used, undistinguished by gender. After anesthesia with ethyl ether, the hearts were put into perfusion (Krebs-Henseleit solution, $95 \% \mathrm{O}_{2}$ and $5 \% \mathrm{CO}_{2}, 37^{\circ} \mathrm{C}$, $110-120 \mathrm{mmHg}$ ), in disposable Langendorff type system. Five groups of six animals were constituted: GI- Control; GII- Ischemia; GIIIIPC; GIV- Ischemia +100 mcg of midazolam; GV- IPC +100 mcg of midazolam. After stabilization $\left(\mathrm{t}_{0}\right)$, and on times $\mathrm{t}_{5}, \mathrm{t}_{10}, \mathrm{t}_{15}, \mathrm{t}_{20}$ and $\mathrm{t}_{25}$, $\mathrm{CF}$, Cflo, systolic pressure (SP) and diastolic pressure (DP) and dP/dt were recorded. DP was maintained at $5 \pm 2 \mathrm{mmHg}$. The statistical method ANOVA and Tukey Test were employed for $\mathrm{p} \leq 0.05$. Results: No significant variations have occurred between Cflo and CF. On $\mathrm{Pd} / \mathrm{td}$, differences have occurred $(\mathrm{p}<0.05)$ between groups I and II (respectively $94.7 \pm 23.0$ and $62.3 \pm 12.1 \%$ ). The preconditioning (GIII), improved significantly the results in the group II (respectively $62.3 \pm 12.1$ and $87.1 \pm 12.4 \%$ ). The decrease in $\mathrm{dP} / \mathrm{dt}$ in group II was not prevented by midazolam (GIV) $(62.3 \pm 12,1$ and $60.5 \pm 15.8 \%)$. In group III, $\mathrm{dP} / \mathrm{dt}$ was $87.1 \pm 12.4 \%$, whereas in group V, only $55.5 \pm 17.2 \%(p<0.05)$ Conclusion: Midazolam, when administered before the ischemia, was unable to prevent the ischemic deterioration of the myocardium. When administered before the preconditioning, it has abolished its protective effect.
\end{abstract}

Key words: Ischemic Preconditioning. Heart. Midazolam. Rats.

\section{RESUMO}

Objetivo: Estudar os efeitos do benzodiazepínico midazolam no fluxo coronariano (Fco), freqüência cardíaca (FC) e contratilidade miocárdica de corações isolados de ratos submetidos ao precondicionamento isquêmico (PCI). Métodos: Foram utilizados 30 ratos Wistar sem distinção de sexo. Após anestesia com éter etílico, os corações foram postos em perfusão (solução de Krebs-Henseleit, 95\% de $\mathrm{O}_{2}$ e $5 \%$ de $\mathrm{CO}_{2}, 37^{\circ} \mathrm{C}, 110-120 \mathrm{mmHg}$ ), em sistema tipo Langendorff descartável. Foram constituídos cinco grupos de seis animais: GI- Controle; GII- Isquemia; GIII- PCI; GIV- Isquemia + 100mcg de midazolam ; GV- PCI + 100mcg de midazolam. Após estabilização $\left(t_{0}\right)$, e nos tempos $t_{5}, t_{10}, t_{15}, t_{20}$ e $t_{25}$, foram registrados a FC, Fco, pressões sistólica (PS) e diastólica (PD) e dP/dt. A PD foi mantida em 5 $\pm 2 \mathrm{mmHg}$. Empregou-se método estatístico ANOVA e Teste de Tukey para $\mathrm{p} \leq 0,05$. Resultados: Não ocorreram variações significantes entre FCo e FC. Na dP/dt, ocorreram diferenças $(\mathrm{p}<0,05)$ entre os grupos I e II (respectivamente 94,7 $\pm 23,0$ e $62,3 \pm 12,1 \%$ ). O precondicionamento (GIII), melhorou significantemente os resultados do grupo II (respectivamente $62,3 \pm 12,1$ e $87,1 \pm 12,4 \%$ ). A queda

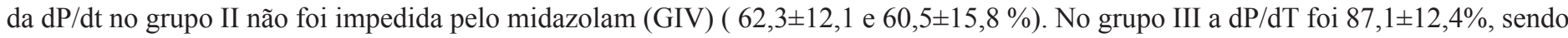
que no grupo $\mathrm{V}$, apenas $55,5 \pm 17,2 \%(\mathrm{p}<0,05)$. Conclusão: $\mathrm{O}$ midazolan quando administrado antes da isquemia não impediu deterioração isquêmica do miocárdio. Quando administrado antes do precondicionamento aboliu seu efeito protetor.

Descritores: Precondicionamento Isquêmico. Coração. Midazolan. Ratos.

${ }^{1}$ Research performed at Research Laboratory, São Francisco de Assis Cardiovascular Foundation, Belo Horizonte - MG, Brazil.

\section{Introduction}

The first demonstration of the potential to reduce the extension of myocardial injury and heart attack in the coronary occlusion was made by Murry et al. ${ }^{1}$ using canine models. These researchers stated that the occlusion of the left circumflex coro- nary artery of the animals for 40 minutes resulted in heart attack in the ischemic area. Using four cycles of ischemia for 5 minutes, alternating with reperfusion, the heart attack area was significantly reduced, reaching to the conclusion that this procedure, named ischemic preconditioning (IPC), allows higher resistance to subsequent extended ischemia. 
Yellon et $a .^{2}$ demonstrated that the protection through IPC also occurs in the human myocardium, which raised a great interest regarding this study.

In cardiology, benzodiazepines, including midazolam, are used as anxiolytics and sleep inducers. They are also used as pre-anesthetic medication, before surgeries and diagnosis and therapeutic procedures that have repercussion in the myocardial perfusion and feasibility.

Midazolam acts in the central nervous system similarly to other benzodiazepines, and potentializes the effects of the GammaAmino Butyric acid (GABA), the main inhibition mediator of the $\mathrm{CNS}^{3}$.

Hernández ${ }^{4}$, Pontes ${ }^{5}$, and Medeiros et al. ${ }^{6}$ demonstrated, in isolated hearts of rats, inhibition of the myocardial contractility after diazepam, midazolam and propofol infusion, and the depressive myocardial effect of midazolam was confirmed by Hekerdemian et al. ${ }^{7}$ and Ozturk et al. ${ }^{8}$.

The present study has the purpose to analyze the influence of midazolam in the ischemic preconditioning induced in isolated hearts of rats.

\section{Methods}

The ethical principles of animal testing were followed, which have been established by the Brazilian School of Animal Testing (Colégio Brasileiro de Experimentação Animal $(\mathrm{COBEA})^{9}$. Isolated hearts of 30 Wistar albino rats were used, undistinguished by gender, with weight ranging from 210 and $340 \mathrm{mg}$, an average of $269 \mathrm{mg}$. The weight of the hearts ranged from $0.74 \mathrm{~g}$ and $1.95 \mathrm{~g}$, an average of $1.29 \mathrm{~g}$. After the procedures of inhaled anesthesia with ethyl ether, systemic heparin infusion and thoracotomy, the hearts were isolated and immediately put into perfusion with Krebs-Henseleit solution, balanced with $95 \% \mathrm{O}_{2}$ and $5 \% \mathrm{CO}_{2}$, and maintained under controlled temperature and pressure perfusion conditions, in a disposable equipment based on the model primarily described by Langendorff. The blood pressure and cardiac frequency records were processed by a biomonitor and printed for analysis and comparative study in a matrix printer. The coronary flow was graded by the minute volume flowing from the cardiac cavities and collected in a graded glass vial. The hearts were distributed in five groups: GI - Control ( $\mathrm{n}=6)$; GII - Ischemia $(n=6)$; GIII - Ischemic preconditioning, determined by Five minutes of ischemia followed by five minutes of reperfusion before the induction of ischemia maintained for 20 minutes ( $n=6$ ); GIV With coronary perfusion in Krebs-Henseleit solution containing $10 \mathrm{mcg} / \mathrm{ml}$, totaling $100 \mathrm{mcg}$ in one minute, immediately before the beginning of the ischemia by occlusion of the aortic perfusion cannula $(n=6) ; \mathrm{GV}$ - With coronary perfusion with midazolam (100mcg), immediately before the beginning of the ischemia for the preconditioning $(n=6)$. After the 15 minutes period of stabilization (time $\left.\mathrm{t}_{0}\right)$, and after $5 \mathrm{~min}\left(\mathrm{t}_{5}\right), 10 \mathrm{~min}\left(\mathrm{t}_{10}\right), 15 \mathrm{~min}\left(\mathrm{t}_{15}\right), 20 \mathrm{~min}$ $\left(t_{20}\right)$ and $25 \mathrm{~min}\left(\mathrm{t}_{25}\right)$, the cardiac frequency $(\mathrm{CF}-\mathrm{bpm})$, coronary flow (Cflo - $\mathrm{ml} / \mathrm{min}$ ), systolic (SP - $\mathrm{mmHg}$ ) and diastolic (DP $\mathrm{mmHg}$ ) blood pressures were recorded. Diastolic pressure was adjusted and maintained at $5 \pm 2 \mathrm{mmHg}$, except during the periods of induced ischemia, when it was maintained at zero. The effects on the myocardial contractility were measured by calculating the values of the first ventricular pressure temporal derivate $(\mathrm{dP} / \mathrm{dt})$. Data obtained in the experiment were analyzed by the ANOVA statistical method, combined with the Tukey Test, with significance level of $95 \%(\mathrm{p} \leq 0.05)$, and the control values $\left(\mathrm{t}_{0}\right)$ and the ones obtained with 20 minutes of myocardial reperfusion $\left(t_{20}\right)$ were considered for comparison.

\section{Results}

No significant statistical differences have occurred between the results of the groups studied regarding the coronary flow and the cardiac frequency. Differences were verified $(p<0.05)$ in the systolic pressure values between groups I and II (respectively, $97.3 \pm 5.8$ and $58.0 \pm 18.0 \%$ against the baseline), II and III (58.0 \pm 18.0 and $87.1 \pm 12.4 \%)$, II and IV (58.0 \pm 18.0 and $74.3 \pm 9.9 \%)$ and III and $\mathrm{V}(87.1 \pm 12.4$ e $55.5 \pm 17.2 \%)$. Regarding $\mathrm{dP} / \mathrm{dt}$, differences were stated $(\mathrm{p}<0.05)$ between groups I and II (respectively, 94.7 \pm 23.0 and $62.3 \pm 12.1 \%$ against the baseline value observed), showing the deleterious effect of the ischemia (group II). Group III presented significantly better results than group II (respectively $62.3 \pm 12.1$ and $87.1 \pm 12.4 \%$ ). Myocardial depression determined by the ischemia (group II) was not prevented by the administration of midazolam (group IV), obtaining, respectively, the values of $62.3 \pm 12.1$ and $60.5 \pm 15.8 \%$ at $\mathrm{dP} / \mathrm{dt}$. However, in group III, with preconditioning without midazolam, the average percentile value of $\mathrm{dP} / \mathrm{dt}$ was $87.1 \pm 12.4 \%$, whereas in group $\mathrm{V}$, with midazolam preconditioning, was only $55.5 \pm 17.2 \%(\mathrm{p}<0,05)$. Results can be observed in Table 1 and Figure 1.

TABLE 1 - Percentage assessment of the variables studied in the constituted groups (values obtained in time $t_{20}$ )

\begin{tabular}{c|c|c|c|c|c}
\hline \multirow{2}{*}{ VARIABLES } & \multicolumn{5}{|c}{ GROUPS } \\
\cline { 2 - 6 } & GI & GII & GIII & GIV & GV \\
\hline Cflo & $83.8 \pm 6.7$ & $83.0 \pm 22.3$ & $79.7 \pm 18.5$ & $69.0 \pm 7.6$ & $72.5 \pm 19.7$ \\
\hline CF & $92.5 \pm 12.2$ & $88.8 \pm 13.9$ & $101.5 \pm 19.7$ & $85.2 \pm 10.8$ & $83.2 \pm 13.3$ \\
\hline SP & $97.3 \pm 5.8$ & $58.0 \pm 18.0^{*}$ & $83.0 \pm 8.9^{*}$ & $74.3 \pm 9.9^{*}$ & $69.2 \pm 15.1^{*}$ \\
\hline $\mathrm{dP} / \mathrm{dt}$ & $94.7 \pm 23.0$ & $62.3 \pm 12.1^{*}$ & $87.1 \pm 12.4^{*}$ & $60.5 \pm 15.8^{*}$ & $55.5 \pm 17.2^{*}$ \\
\hline
\end{tabular}

Cflo - Coronary flow, $\mathbf{C F}$ - Cardiac frequency, $\mathbf{S P}$ - systolic pressure, $\mathrm{dP} / \mathrm{dt}$ - Pressure/time temporal derivate, ${ }^{*} \mathrm{p}<0.05$. 


\section{Variação Percentual da dP/dt nos Grupos Estudados}

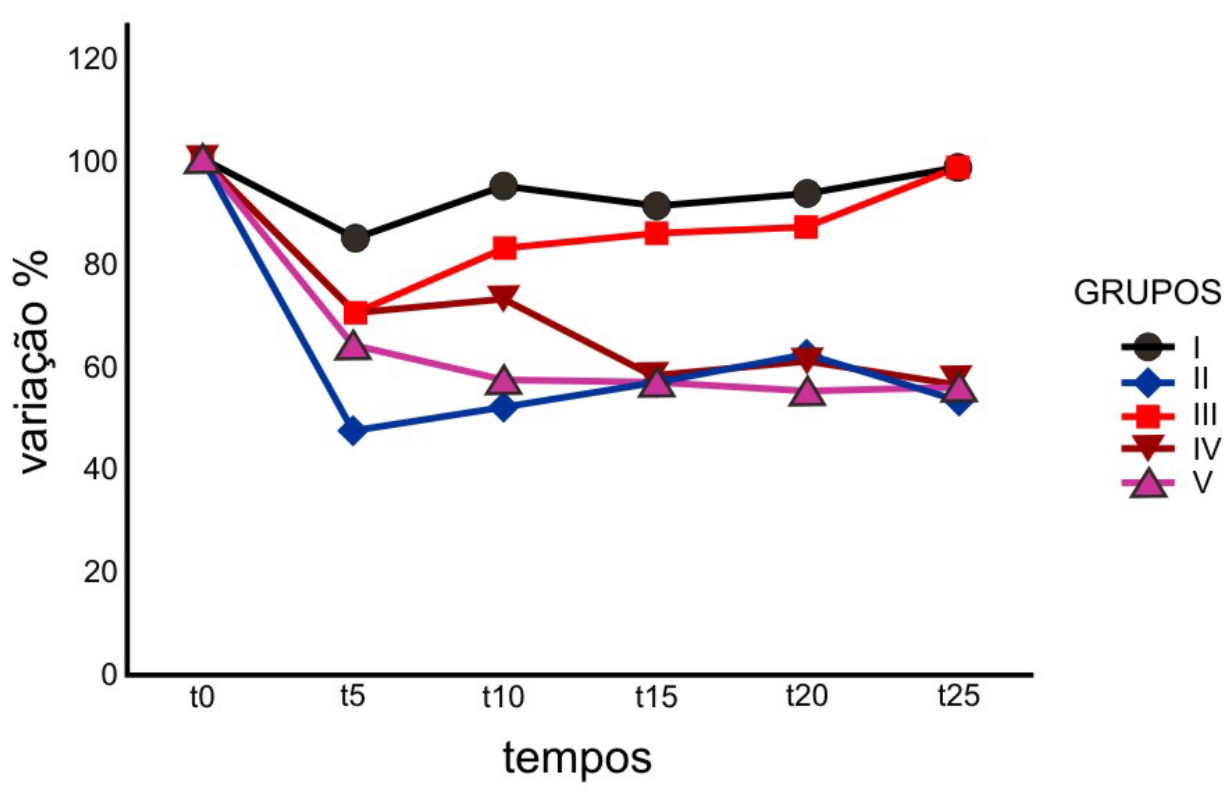

FIGURE 1 - Percentile variation of $\mathrm{dP} / \mathrm{dt}$ in studied groups

\section{Discussion}

Jennings and Reimer ${ }^{10}$ showed that even though the reperfusion is essential to protect the ischemic myocardium, it doesn't prevent the death of cardiomyocytes, especially if the ischemia is prolonged.

The first demonstration of the likelihood to reduce the number of cardiac cells dead after the IAM was made by Murry et al. ${ }^{1}$. These researchers stated that the occlusion of the left circumflex coronary artery of dogs for 40 minutes resulted in heart attack of $29.4 \pm 4.4 \%$ of the ischemic area. If, before the occlusion, the animals were subjected to four cycles of 5 minutes of ischemia, alternating with 5 minutes of reperfusion, the area attacked would be reduced to $7.3 \pm 2.1 \%$, and the authors named this protective effect as "ischemic preconditioning", which gained worldwide interest due to its applicability potential, especially after Yellon et al. ${ }^{2}$ has show that this also occurs in the human myocardium.

Even though the IPC mechanism is not entirely clarified, it is known that immediately after the ischemia, the organism increases the production of several chemical mediators that trigger the cardio protection process ${ }^{11}$. Amongst these mediators, the most important ones seem to be acetilcholyne ${ }^{12}$, angiotensin $\mathrm{II}^{13}$, and mainly adenosine ${ }^{14}$. The connection of these substances to their receptors in the external surface of the sarcolem starts the next phase that occurs in the cytosol. In this second phase, signalization routes are activated with several stages, in which participate several substances reactive to oxygen ${ }^{15}$, phospholipase, diacylglycerol (DAG) and inositol ${ }^{16}$. Finally, these routes seem to converge mainly to activate the protein kinase (PKC) enzyme, which interacts with mitocondrial ${ }^{17,18}$ structures, resulting in alteration of the cellular metabolism and under cardio protection.

Currently, numerous researches on IPC have the purpose to clarify its biochemical mechanism, pursuing the development of drugs that induce the safe and effective cardiac preconditioning.

Benzodiazepines, even though widely used as pre-anesthetic or sedatives in procedures that can cause myocardial ischemia, have effects on the IPC that are not well known. However, works by several researchers have evidenced negative inotropic effects of these substances on the heart, including for midazolam. In 1991, Hernández ${ }^{4}$ observed the depressive effect of diazepam over rats' myocardium. Shekerdemian et al. ${ }^{18}$ reported the reduction of $24.1 \%$ in cardiac debt in human hearts perfused with midazolam during heart surgery. In the same year, Nonaka et al. ${ }^{19}$, observed the negative inotropic effect of diazepam and midazolam in a culture of rats' cardiomyocytes. Ozturk et al. ${ }^{8}$ observed that midazolam, in doses ranging from $10 \mathrm{mcg}$ and $100 \mathrm{mcg}$, have caused myocardium depression in rabbits. Medeiros et al. ${ }^{6}$, studying the effects of diazepam, midazolam and propofol in isolated hearts of rats, reported that benzodiazepines have caused depression in myocardial contractility.

The present investigation confirms the data initially reported $^{19}$, showing that the statistical comparison of $\mathrm{dP} / \mathrm{dt}$ values in the groups ischemia (GII) and IPC (GIII) confirm the protective effects of the IPC in the ischemic myocardium. It could also be observed that midazolam, when associated to the IPC procedure $(\mathrm{GV})$, caused a significant reduction in myocardial contractility $(\mathrm{dP} / \mathrm{dt})$, if compared to the same procedure without using the medication (GIII).

Even though the statistical analysis didn't show significant differences in $\mathrm{CF}$ and Cflo in the groups studied, it could be stated that the biggest percentile reductions of these variables, in time, have occurred in those subjected to the ischemia (GII) and in those treated with midazolam (GIV e GV).

Regarding SP, significant statistical differences were observed between the control (GI) and ischemia (GII) groups, showing the harmful effects of the ischemia on the heart. Significant statistical differences could also be observed in this variable between the ischemia (GII) and IPC (GIII) groups, confirming the protective effect of the IPC in the myocardium. The administration of midazolam (GIV) has not prevented the functional depression determined by the ischemia without IPC (GII) and has blocked, in group IV, the beneficial effect dependent of the preconditioning without drugs, observed in group III.

The choice for anesthesia with F.A. ether constitutes a special aspect in the method employed, and, in the recent past, in other surveys made by our Institution, the acquisition and use of ether without the specification "For Analysis" has resulted in functional damages to the isolated hearts under study. The use of F.A. ether enabled a stable cardiac performance in the control group and full effect of the preconditioning in the group studied without midazolam. 
The limitations of the present study include the biologic difficulty to correlate animal testing data with similar situations in humans, the number of experiments carried out so far and also not analyzing the morphology variations, especially in the ultramicroscopic level, to differentiate between tissue injury and functional limitation. However, the results obtained confirm in rats the recent publication of Rivo et al. ${ }^{20}$ describing similar effects of midazolam abolishing the preconditioning in rabbit hearts.

\section{Conclusion}

Midazolam has not interfered significantly in the cardiac frequency and coronary flow in the groups analyzed. It has not protected the myocardium of the investigated group with induced ischemia and, when associated to IPC, has prevented the protection of myocardial contractility $(\mathrm{dP} / \mathrm{dt})$ if compared to the same procedure without the medication.

\section{References}

1. Murry CE, Jennings RB, Reimer KA. Preconditioning with Ischemia: a delay of lethal injury in ischemic myocardium. Circulation. 1986;74:1124-36.

2. Yellon DM, Aikhulaifi AM, Pugsley WB. Preconditioning the human myocardium. Lancet. 1993;88:1264-72.

3. Hekerdemian L, Bush A, Redington A. Cardiovascular effects of intravenous midazolam after open heart surgery. Arch Dis Child. 1997;76:57-61.

4. Hernàndez J. The negative inotropic effect of Diazepam in rat right ventricular strips. J Pharm Pharmacol. 1991;43:879-81.

5. Pontes JCDV. Análise comparativa dos efeitos do diazepam, midazolam e propofol na contratilidade miocárdica. Estudo em corações isolados de ratos. Rev Bras Cir Cardiovasc. 1995;4(10):165-74.

6. Medeiros CGS, Pontes JCDV, Gomes OM, Silva LPRG. Análise comparativa dos efeitos do diazepam, midazolam, propofol e etomidato na contratilidade miocárdica e no fluxo coronariano: estudo em corações isolados de ratos. Rev Bras Cir Cardiovasc. 2004;19(2):157-64.

7. Hekerdemian L, Bush A, Redington A. Cardiovascular effects of intravenous midazolam after open heart surgery. Arch Dis Child. 1997;76:57-61.
8. Ozturk T, Tunkok Y, Kalkan S, Guven H, Aran G. Midazolam's cardiac depressant effect and their lack of reversal by flumazenil in isolated rabbit hearts. Pharmacol Res. 1999;39(4):283-7.

9. Colégio Brasileiro de Experimentação Animal COBEA. Princípios éticos na experimentação animal. [acesso 2008 jun 4]. Disponível em http:// www.cobea.org.br/etica.htm\#3.

10. Jennings RB, Reimer KA. Factors involved in salvaging ischemic myocardium: effects of reperfusion of arterial blood. Circulation. 1983;68:125-36.

11. Liu H, McPherson BC, Yao Z. Preconditioning attenuates apoptosis and necrosis: role of protein kinase CE and - 6 isofarms. Am J Physiol Heart Ore Physiol. 2001;281:404-10.

12. William M, Garrett JG. Prologue: ischemie preconditioning in cardiac vascular muscle. Am J Physiol Heart Circ Physiol. 1999;277:2416-7.

13. Das DK, Maulik N, Engelman RM. Redox regulation of angiotensin 11 signaling in the heart. J Cell MoI Med. 2004;8(1):144-52.

14. Skalova K, Luptak I, Matuskova J, Tureani M, Hulin I. Adenosine and cardioprotection: What ean we learn from nature's genetie polymorphism? Bratisl Lek Listy 2002;103(6):187-93.

15. Zhenrai Y, Tong J, Xiaohui J, Changqing L, Zuohui C, Kim CW, Vanden Hoe TL, Beeker LB, Head CA, Schumacker PT. Role of reactive oxygen species in acetylcholine-induced preconditioning in cardiomyocytes. Am J Physiol Heart Circ Physiol. 1999;277:2504-9.

16. Santos P, Kowaltowski A, Laclau MN, Seetharaman S, Paucek P, Boudina S, Thambo JB, Tariosse L, Garlid KD. Mechanisms by wich opening the mitochondrial ATP-sensitive $\mathrm{K}+$ channel protects the ischemic heart. Am J Physiol Heart Circ Physiol. 2002;283:284-95.

17. Derek JH, Maddock LH, Baxter GF, Yellon MD. Inhibiting mitochondrial permeability transition pore opening: a new paradigm for myocardial preconditioning?. Cardiovasc Res. 2002;55:534-43.

18. Shekerdemian L, Bush A, Redington A. Cardiovascular effects of intravenous midazolam after open heart surgery. Arch Dis Child. 1997;76:57-61.

19. Nonaka A, Kashimito S, Imamura M, Furuya A, Kumazawa T. Mechanism of negative inotropic effect of midazolam and diazepam in cultured foetal mouse cardiac myocites. Eur J Anesth. 1997;14:481-7.

20. Rivo J, Raphael J, Drenger B, Berenstein E, Chevion M, Gozal Y. Flumazenil mimics whereas midazolam abolishes ischemic preconditioning in a rabbit heart model of ischemia-reperfusion. Anesthesiology. 2006;105(1):65-71.

Conflict of interest: none Financial source: none

\section{Correspondence:}

Otoni Moreira Gomes

Rua José do Patrocínio, 522

31525160 Belo Horizonte - MG Brazil

gomes@servcor.com

Received: December 18, 2008

Review: February 10, 2009

Accepted: March 12, 2009

\section{How to cite this article}

Gomes OM, Valladares UF, Santos CHM, Abrantes RD. Preconditioning abolishion by midazolam in isolated hearts of rats. Acta Cir Bras. [serial on the Internet] 2009 May-Jun;24(3). Available from URL: http://www.scielo.br/acb 